\title{
Emetic toxin-producing strains of Bacillus cereus show distinct characteristics within the Bacillus cereus group
}

\author{
Frédéric Carlin ${ }^{\mathrm{a},{ }^{\star}}$, Martina Fricker ${ }^{\mathrm{b}}$, Annemarie Pielaat ${ }^{\mathrm{c}}$, Simon Heisterkamp ${ }^{\mathrm{c}}$, Ranad \\ Shaheen $^{d}$, Mirja Salkinoja Salonen ${ }^{d}$, Birgitta Svensson ${ }^{\mathrm{e}}$, Christophe Nguyen-the ${ }^{\mathrm{a}}$ and \\ Monika Ehling-Schulz ${ }^{b}$
}

aINRA, UMR 408, Sécurité et Qualité des Produits d'Orgine Végétale, F-84914 Avignon, France

${ }^{b}$ Lehrstuhl für mikrobielle Ökologie, Department der Grundlagen der Biowissenschaften, Technische, Universität München, Weihenstephaner Berg 3, D-85354 Freising, Germany

${ }^{c}$ National Institute for Public Health and the Environment (RIVM), P.O. Box 1, 3720 BA Bilthoven, The Netherlands

dUniversity of Helsinki, Department for Applied Chemistry and Microbiology, College of Agriculture and Forestry at the University of Helsinki, Viikinkaari 9, PO Box 56, FIN 00014 University of Helsinki, Finland

${ }^{e}$ Swedish Dairy Association, Scheelevaegen 18, 22363 Lund, Sweden

* Corresponding author. Unité Mixte de Recherche Sécurité et Qualité des Produits d'Orgine Végétale, INRA, Site Agroparc, 84914 Avignon cedex 9, France. Tel.: +33 4327225 19; fax: +33432722492.

\section{Abstract}

One hundred representative strains of Bacillus cereus were selected from a total collection of $372 B$. cereus strains using two typing methods (RAPD and FT-IR) to investigate if emetic toxin-producing hazardous $B$. cereus strains possess characteristic growth and heat resistance profiles. The strains were classified into three groups: emetic toxin (cereulide)producing strains $(n=17)$, strains connected to diarrheal foodborne outbreaks $(n=40)$ and food-environment strains $(n=43)$, these latter not producing the emetic toxin. Our study revealed a shift in growth limits towards higher temperatures for the emetic strains, regardless of their origin. None of the emetic toxin-producing strains were able to grow below $10^{\circ} \mathrm{C}$. In contrast, $11 \%$ ( 9 food-environment strains) out of the 83 non-emetic toxin-producing strains were able to grow at $4{ }^{\circ} \mathrm{C}$ and $49 \%$ at $7{ }^{\circ} \mathrm{C}$ (28 diarrheal and 13 food-environment strains). non-emetic toxin-producing strains. All emetic toxin-producing strains were able to grow at 48 ${ }^{\circ} \mathrm{C}$, but only $39 \%$ (16 diarrheal and 16 food-environment strains) of the non-emetic toxinproducing strains grew at this temperature. Spores from the emetic toxin-producing strains showed, on average, a higher heat resistance at $90^{\circ} \mathrm{C}$ and a lower germination, particularly at $7{ }^{\circ} \mathrm{C}$, than spores from the other strains. No difference between the three groups in their growth kinetics at $24{ }^{\circ} \mathrm{C}, 37{ }^{\circ} \mathrm{C}$, and $\mathrm{pH} 5.0,7.0$, and 8.0 was observed. Our survey shows that emetic toxin-producing strains of $B$. cereus have distinct characteristics, which could have important implication for the risk assessment of the emetic type of $B$. cereus caused food poisoning. For instance, emetic strains still represent a special risk in heat-processed foods or preheated foods that are kept warm (in restaurants and cafeterias), but should not pose a risk in refrigerated foods.

\section{Introduction}

The endospore-forming bacterium Bacillus cereus, which is commonly isolated from food, can cause foodborne illness, either an emetic or a diarrheal syndrome. The emetic syndrome is caused by the ingestion of the heat-stable emetic toxin (cereulide, a cyclic peptide of $1.2 \mathrm{kDa}$ ) produced in foods. The diarrheal syndrome is mainly due to the ingestion of $B$. cereus cells in the foods, followed by toxin production in the small intestine (Kramer and Gilbert, 1989 and Granum and Lund, 1997). A significant progress has recently been made in the biochemical 
and biological detection of the $B$. cereus emetic toxin, and in the molecular detection of the emetic and of the diarrheal toxins genes. A LC-MS method has been developed to detect the emetic toxin production (Jääskeläinen et al., 2003 and Andersson et al., 2004) and the first molecular tools for the detection of emetic strains of $B$. cereus have been designed (EhlingSchulz et al., 2004 and Ehling-Schulz et al., 2005a). Both methods allow a reliable detection of potential emetic toxin-producing strains within the $B$. cereus species.

The species $B$. cereus covers a huge diversity in genetic characters (Guinebretière and Sanchis, 2003, Helgason et al., 2004 and Hill et al., 2004), virulence factors (Beattie and Williams, 1999, Choma et al., 2000, Helgason et al., 2004 and Hill et al., 2004) and survival or growth characteristics (Dufrenne et al., 1994, Dufrenne et al., 1995, Choma et al., 2000 and Nguyen-the et al., 2003). However there is some evidence that emetic toxin-producing strains form a distinct cluster within $B$. cereus with some specific characters (such as the inability to hydrolyse starch) (Shinagawa, 1990, Agata et al., 1996, Pirttijarvi et al., 1999 and EhlingSchulz et al., 2005b). The aim of this work is to determine whether emetic toxin-producing strains of $B$. cereus differ from the other strains of $B$. cereus, not producing the emetic toxin regarding their growth characteristics and their heat resistance to assess the risks of different types of food/ food preparation/food handling for emetic toxin production. For this purpose, a panel that comprises 100 strains of foodborne, environmental, and clinical strains of $B$. cereus, gathered by participants in an EU-funded project, was compiled.

\section{Materials and methods}

\subsection{Strains}

A collection of $100 \mathrm{~B}$. cereus strains was compiled for this study (Table 1). The strain set includes clinical isolates and isolates from food remnants connected to both emetic $(n=10)$, and diarrheal foodborne outbreak $(n=40)$, and isolates from food $(n=35)$ and from the environment $(n=15)$. 
Table 1.

Origin of $B$. cereus strains

\begin{tabular}{|c|c|c|}
\hline $\begin{array}{l}\text { Type of } B . \\
\text { cereus } \\
\text { strains }\end{array}$ & Strain designation & Origin \\
\hline \multirow[t]{3}{*}{$\begin{array}{l}\text { Emetic toxin- } \\
\text { producing } \\
\text { strains }\end{array}$} & $\begin{array}{l}\text { F3080B/87, F3351/87, F4810/72 (DSM4312), IH41385 a, }, \text { MHI 1305, NC7401, } \\
\text { RIVM BC 124, RIVM BC 67, UHDAM B315, UHDAM ML127 }\end{array}$ & $\begin{array}{l}\text { Emetic } \\
\text { outbreak; } \\
\text { clinical }(n=10)\end{array}$ \\
\hline & MHI 87, RIVM BC379, SDA GR177, UHDAM CIF1, UHDAM CIF3 & Food $(n=5)$ \\
\hline & UHDAM 3/pkl, UHDAM NS-115, & $\begin{array}{l}\text { Environment } \\
(n=2)\end{array}$ \\
\hline \multirow[t]{3}{*}{$\begin{array}{l}\text { Strains not } \\
\text { producing the } \\
\text { emetic toxin }\end{array}$} & $\begin{array}{l}\text { 98HMPL63 }{ }^{\mathrm{c}} \text {, F2081A/98, F2085/98, F3371/93, F3453/94, F352/90, F4430/73 } \\
\text { (DSM 4384, B4ac), F4433/73, F528/94, F837/76 (DSM 4222), FH3502/72 (DSM } \\
\text { 2301), IH41064a }{ }^{\mathrm{a}} \text { MHI 203, DSM 8438 (NRS 404), NVH 0075-95, NVH 0154-01, } \\
\text { NVH 0165-99, NVH 0226-00, NVH 0230-00, NVH 0309-98, NVH 0391-98, NVH } \\
\text { 0500-00, NVH 0597-99, NVH 0674-98, NVH 0784-00, NVH 0861-00, NVH 1104- } \\
\text { 98, NVH 1105-98, NVH 1230-88, NVH 141/1-01, NVH 1518-99, NVH 1519-00, } \\
\text { NVH 1651-00, NVH 200, RIVM BC 122, RIVM BC 63, RIVM BC 90, UHDAM } \\
\text { B106, UHDAM B154, UHDAM B217 }\end{array}$ & $\begin{array}{l}\text { Diarrhoeal } \\
\text { outbreak } \\
(n=40)\end{array}$ \\
\hline & $\begin{array}{l}\text { INRA 1, INRA A3, INRA C24, INRA C3, INRA C57, INRA I20, INRA I21, INRA } \\
\text { PA, MHI 124, MHI 13, MHI 32, NVH 445, NVH 449, NVH 506, RIVM BC 485, } \\
\text { RIVM BC 934, RIVM BC 938, RIVM BC 964, SDA GR285, SDA KA96, SDA } \\
\text { MA57, UHDAM 1IFI(13), UHDAM B102, WSBC10030, WSBC10204, } \\
\text { WSBC10286, WSBC10377, WSBC10395, WSBC10466, WSBC10483 }\end{array}$ & Food $(n=30)$ \\
\hline & $\begin{array}{l}\text { INRA SZ, NVH 460, NVH 512, NVH 655, SDA 1R177, SDA 1R183, SDA 1R72, } \\
\text { SDA NFFE640, SDA NFFE647, SDA NFFE664, UHDAM TSP9, WSBC10310, } \\
\text { WSBC10441 }\end{array}$ & $\begin{array}{l}\text { Environment } \\
(n=13)\end{array}$ \\
\hline
\end{tabular}

INRA, Institut National de la Recherche Agronomique, UMR408, Avignon, France; SDA, Svensk Mjolk, Swedish Dairy Association, Lund Sweden; WSBC: Weihenstephan Bacillus cereus collection, Weihenstephan, Germany; DSM, Deutsche Sammlung für Mikroorganismen und Zellkulturen, Braunschweig, Germany; F strains were obtained from the Public Health Laboratory Service (PHLS), London, UK; NVH, The Norwegian School of Veterinary Science, Oslo, Norway; RIVM, Rijksinstituut voor Volksgezondheid en Milieu, Bilthoven, The Netherlands; UHDAM, University of Helsinki, Department of Applied Chemistry and Microbiology, Helsinki, Finland; MIH strains were obtained from the Ludwig MaximiliansUniversität, München, Germany.

${ }^{a}$ From University of Helsinki, Department of Applied Chemistry and Microbiology, Helsinki, Finland.

${ }^{b}$ Strain IH41385 is a clinical isolate from dialysis liquid connected to illness.

${ }^{\mathrm{c}}$ From Agence Française de Sécurité Sanitaire des Aliments, AFSSA, France.

To ensure a large diversity in these 100 strains, they were selected from a first set of 372 isolates provided by the various participants and isolated in various countries. These 372 strains included strains from various foods and food processing chains (dairy, vegetables, recipe dishes containing meat, sea foods, rice, pasta and bakery product), strains from the environment (soil and surface water), and strains implicated in foodborne poisoning cases. All strains were typed using two different typing methods, i.e. is random amplification of polymorphic DNA and Fourier transformed infrared spectroscopy, as described in EhlingSchulz et al. (2005b). Isolates with similar profiles were eliminated. A Microsoft Access database was designed and used to generate a panel of 100 representative strains. Selection criteria were: (i) largest diversity in strain profiles, (ii) largest diversity in geographical origins, and (iii) keep 50 strains from clinical foodborne poisoning cases and 50 strains from both food and the environment. 


\subsection{Detection of $B$. cereus strains producing the emetic toxin}

$B$. cereus emetic toxin (cereulide)-producing strains were detected by both production of cereulide, assayed with liquid chromatography-mass spectrometry (Jääskeläinen et al., 2003), and by detection of cereulide gene synthase (ces) using a recently developed PCR assay (Ehling-Schulz et al., 2005a). Both methods were applied to the entire test panel. $B$. cereus biomass ( 5 to $10 \mathrm{mg}$ wet wt) grown on TSA plates (Difco, Becton Dickinson, Maryland USA) was extracted in $200 \mu \mathrm{l}$ methanol in a capped tube $(4 \mathrm{ml})$ in boiling water bath for 15 min. The cooled, filtered $(0.45 \mu \mathrm{m})$ extract was used for LC-MS analysis, based on four molecular ions specific for cereulide $\left(\mathrm{H}^{+}, \mathrm{NH}_{4}{ }^{+}, \mathrm{K}^{+}\right.$and $\mathrm{Na}^{+}$adducts), performed as described elsewhere (Jääskeläinen et al., 2003). DNA extraction and PCR using the sequences of the cereulide synthetase specific primers were performed as described previously (Ehling-Schulz et al., 2005a).

\subsection{Determination of temperature growth limits}

Growth tests were performed in Plate count (PC) broth $(5 \mathrm{~g}$ of casein peptone, $2.5 \mathrm{~g}$ of yeast extract, $1 \mathrm{~g}$ of glucose/l, with a pH adjusted to 7.0 ). Bacteria were grown for $18 \mathrm{~h}$ in $5 \mathrm{ml} \mathrm{PC}$ broth at $30{ }^{\circ} \mathrm{C}$ and $170 \mathrm{rpm}$. Fresh PC broth $(5 \mathrm{ml})$ was inoculated with $10 \mu \mathrm{l}$ of the overnight cultures (corresponding to approx. $10^{5} \mathrm{cfu} / \mathrm{ml}$ ), and incubated at different temperatures, at 170 rpm. Lower growth limits were tested at $4{ }^{\circ} \mathrm{C}, 7^{\circ} \mathrm{C}$ and $10^{\circ} \mathrm{C}$, upper growth limits at $45^{\circ} \mathrm{C}$ and $48{ }^{\circ} \mathrm{C}$; in addition, strains that did not grow at $45^{\circ} \mathrm{C}$ were also tested at $42{ }^{\circ} \mathrm{C}$ and those that grew at $48{ }^{\circ} \mathrm{C}$ were also tested at $52{ }^{\circ} \mathrm{C}$. The tubes were sealed with parafilm to avoid evaporation and concentration of the liquid medium at higher temperatures. Growth was determined via optical density at $585 \mathrm{~nm}$ with a portable WinLab photometer LF2400 (Windaus Labortechnik, Germany) after 1, 2, 5, 7, 9 and 12 days. In addition, growth was measured with a Perkin-Elmer 550SE UV/VIS spectrophotometer at $600 \mathrm{~nm}$ (Perkin-Elmer, Germany) after 7 and 12 days. Growth was defined as an increase of $O D_{600}$ by at least 0.1 .

\subsection{Growth kinetics at $24{ }^{\circ} \mathrm{C}, 37{ }^{\circ} \mathrm{C}$ and pH 5, pH 7, pH 8}

Growth curves for the test strains were determined with a multiwell photometric plate reader Bioscreen C (Labsystems Corp., Helsinki, Finland). Overnight cultures of the test strains were grown in $5 \mathrm{ml} \mathrm{PC}$ broth, $\mathrm{pH} 7.0$, at $30^{\circ} \mathrm{C}$ and $170 \mathrm{rpm}$. A $10 \mu \mathrm{l}$ aliquot of each culture was diluted in $190 \mu \mathrm{l}$ of PC broth and a $10 \mu \mathrm{l}$ aliquot of this dilution was used to inoculate $240 \mu \mathrm{l}$ of $\mathrm{PC}$ broth (corresponding to approx. $10^{5} \mathrm{cfu} / \mathrm{ml}$ ) with different $\mathrm{pH}$ values in multiwell plates of the Bioscreen C. PC broth was adjusted to $\mathrm{pH} 5$ with $1 \mathrm{M}$ piperazin solution (Aldrich, Germany) and $\mathrm{PC}$ broth with a $\mathrm{pH} 7$ or $\mathrm{pH} 8$ was buffered with $1 \mathrm{M}$ Tris- $\mathrm{HCl}$ solutions having the designated $\mathrm{pH}$. The plates were incubated under continuous shaking in the plate reader at $24^{\circ} \mathrm{C}$ and at $37^{\circ} \mathrm{C}$. OD was recorded every $60 \mathrm{~min}$ for $48 \mathrm{~h}$ with the computer software Biolink (Transgalactic Ltd., Finland, version 5.30). Data were exported to Microsoft Excel for statistical analysis.

\subsection{Heat resistance of $B$. cereus spores}

Purified $B$. cereus stock cultures were grown overnight in JB to produce spores (Claus and Berkeley, 1986) at $30{ }^{\circ} \mathrm{C}$. An aliquot was then spread on duplicate plates of modified Fortified Nutrient Agar (FNA) (Fernández et al., 1999), and incubated at $30^{\circ} \mathrm{C}$ for $3-7$ days.

Sporulation was checked daily by microscopic examination, and spores were harvested when at least $90 \%$ of the cells had produced spores. Strains WSBC10204 and WSBC10310 were unable to produce spores in several attempts. The agar surface was then flooded with $2 \mathrm{ml}$ of sterile cold demineralized water. The spore suspension was twice washed in $2 \mathrm{ml}$ sterile cold distilled water and finally suspended in $2 \mathrm{ml}$ of an aqueous solution of glycerol at $30 \%(\mathrm{v} / \mathrm{v})$. Spore suspensions were stored at $-20{ }^{\circ} \mathrm{C}$ until use. Number of survivors was evaluated after $0,10,20,30,60$ and 120 min of heating at $90{ }^{\circ} \mathrm{C}$. Samples were serially diluted in peptone water and surface spread on JA plates using a spiral plate apparatus (Spiral système, Intersciences, Saint-Nom la Bretèche, France). Cell concentrations were expressed as colony forming units per $\mathrm{ml}$ (cfu/ml) (Choma et al., 2000). Survival curves were fitted to a linear regression model to calculate decimal reduction times ( $D_{90}{ }^{\circ} \mathrm{C}$ values), and, as most survival 
curves diverged from linearity, the non-linear model of Mafart et al. (2002) was used to calculate the time to first decimal reduction $(\delta)$.

\subsection{Germination of $B$. cereus spores}

The method was similar to that used by Dufrenne et al. (1994). Briefly $B$. cereus spores were produced and stored as previously described. A spore suspension containing ca $10^{7}-10^{8} \mathrm{~B}$. cereus spores $/ \mathrm{ml}$ in $100 \mathrm{mM}$ phosphate buffer at $\mathrm{pH} 6.8$ was prepared and pasteurised at 80 ${ }^{\circ} \mathrm{C}$ for $5 \mathrm{~min}$. Aliquots of $100 \mu \mathrm{l}$ were inoculated in tubes containing $9.9 \mathrm{ml}$ of $\mathrm{J}$ broth. The tubes were then incubated at $30^{\circ} \mathrm{C}$ for $50 \mathrm{~min}$ and at $7{ }^{\circ} \mathrm{C} \pm 0.5{ }^{\circ} \mathrm{C}$ for 7 days. After incubation tubes were pasteurised at $80^{\circ} \mathrm{C}$ for 5 min. Spores were counted just after inoculation into tubes and after pasteurisation at the end of incubation, as described above. Two replicate tubes were performed for each incubation temperature. The extent of germination was expressed as the $\log _{10}\left(N_{0} / N\right), N_{0}$ being the initial spore number and $N$ the number of remaining spores after incubation.

\subsection{Statistical analysis}

Differences between emetic toxin-producing strains, diarrheal, and food-environment strains were tested (i) with the Pearson's Chi-square test for upper and lower growth temperatures and (ii) with the Kruskal-Wallis test for heat resistance and germination, using Systat version 9 (SPSS, Chicago, USA). Threshold values were kept for statistical analysis when no accurate value could have been determined.

The non-linear mixed model

$y(t)=\frac{A}{1+e^{-\frac{\left(B-t_{\text {mid }}\right)}{\text { scale }}}} e^{-d_{0} t}+B_{0}$

was used to determine the horizontal final asymptote $A$ (without background $B_{0}$ optical density) of the growth kinetics of all strains at $24^{\circ} \mathrm{C}$ and $37^{\circ} \mathrm{C}$, and pH 5.0, 7.0 and 8.0 (Doucet and Sloep, 1992). In addition, $t_{\text {mid }}$ (time at which $50 \%$ of $A$ is reached) and the slope of each growth curve at $t_{\text {mid }}$ (i.e. $1 / \mathrm{scale}$ ) were estimated. The parameter $d_{0}$ is the rate of decay of the bacteria. The maximum likelihood method was used for statistical analysis (SPLus 6.2 package with the nlme-library).

\section{Results and discussion}

Strains characteristics are shown in Table 2, Table 3 and Table 4. Seventeen out of the 100 strains of the collection both produced cereulide and possessed the ces gene (Table 1 and Table 2). None of the other strains (most importantly, the diarrheal strains) were positive for any of the tests, showing a perfect agreement between detection of the ces gene and cereulide production, although the expression of the ces gene varied 1000-fold between the strains. Table 2 shows that the cereulide productivity in TSA-plate grown $(24 \mathrm{~h})$ cultures ranged from very low ( $<1 \mathrm{ng}$ to $50 \mathrm{ng}$ of cereulide per $\mathrm{mg}$ of bacterial biomass), medium ( $>50$ to $500 \mathrm{ng}$ ) and extremely high amounts ( $>500$ to $1600 \mathrm{ng}$ of cereulide). The present results show that variation in cereulide production between individual strains is even higher than reported in an earlier study of 10 cereulide-producing strains (Andersson et al., 2004). The ces gene detection is hence usable for detecting strains capable of producing cereulide, but, as such, not useful as basis for risk assessment, because it does not account for the differences in the amounts of the emetic toxin produced by the tested strains under identical conditions. None of the 17 emetic toxin-producing strains of $B$. cereus were able to grow at 4 ${ }^{\circ} \mathrm{C}$ or $7{ }^{\circ} \mathrm{C}$, while 50 (28 diarrheal and 22 food-environment strains) out of 83 non-emetic toxin-producing were able to grow at $4{ }^{\circ} \mathrm{C}$ or $7{ }^{\circ} \mathrm{C}$ (the difference in the frequency of strains growing at $7{ }^{\circ} \mathrm{C}$ and below in each category was significant at $P<0.001$ ) (Table 5). This poor ability to grow at temperatures below $10^{\circ} \mathrm{C}$ was linked to a low germination of spores at $7{ }^{\circ} \mathrm{C}$ (difference in the distribution of values for each category of strains significant at $P<0.001$ ). At 
$30{ }^{\circ} \mathrm{C}$, spores of the emetic toxin-producing strains also showed a lower ability to germinate than the strains belonging to the two other categories $(P<0.01)$ (Fig. 1). Germination of the spores of the diarrheal, and food-environment strains were highly similar for both temperatures (Fig. 1). Finlay et al. (2000) determined that the lower limit for growth of 7 tested emetic strains was $12{ }^{\circ} \mathrm{C}$ and Johnson et al., 1982 and Johnson et al., 1983 also observed a lower germination of spores of emetic strains (only three tested) in a range of temperatures and media in comparison to diarrheal strains.

Table 2.

Characteristics of the $B$. cereus emetic toxin-producing strains tested in this work

\begin{tabular}{|c|c|c|c|c|c|c|c|c|c|}
\hline \multirow[t]{2}{*}{ Strain no. } & \multirow[t]{2}{*}{$\begin{array}{l}\text { Associated } \\
\text { to emetic } \\
\text { outbreak }\end{array}$} & \multirow{2}{*}{ 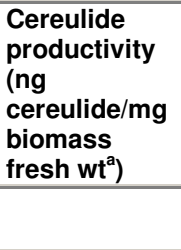 } & \multicolumn{2}{|c|}{$\begin{array}{l}\text { Temperature } \\
\text { growth limits } \\
\left({ }^{\circ} \mathrm{C}\right)\end{array}$} & \multicolumn{3}{|c|}{$\begin{array}{l}\text { Heat resistance } \\
\text { parameters of spores at } \\
90^{\circ} \mathrm{C}^{\mathrm{b}}\end{array}$} & \multicolumn{2}{|c|}{$\begin{array}{l}\text { Germination } \\
\text { of spores at }\end{array}$} \\
\hline & & & Lower $^{\mathrm{d}}$ & Upper ${ }^{\mathrm{e}}$ & $\begin{array}{l}D \\
(\min )\end{array}$ & $\begin{array}{l}\delta \\
(\min )\end{array}$ & $\begin{array}{l}\text { Viability } \\
\text { loss }\end{array}$ & $7^{\circ} \mathrm{C}$ & $\begin{array}{l}30 \\
{ }^{\circ} \mathrm{C}\end{array}$ \\
\hline F3080B/87 & Yes & 500 & $>10$ & 48 & 372 & 130 & 0.80 & 0.20 & 2.03 \\
\hline F3351/87 & Yes & 20 & 10 & 48 & 537 & $>120$ & 0.61 & 0.23 & 2.47 \\
\hline F4810/72 & Yes & $240-600$ & 10 & 48 & 763 & $>120$ & 0.35 & 0.10 & 1.92 \\
\hline $\mathrm{IH} 41385$ & No & $0.5-1$ & $>10$ & 48 & 917 & $>120$ & 0.28 & 0.21 & 2.03 \\
\hline MHI 1305 & Yes & $170-200$ & $>10$ & 48 & 672 & $>120$ & 0.80 & 0.29 & 1.17 \\
\hline MHI 87 & No & $70-110$ & $>10$ & 48 & 318 & 23 & 1.24 & 0.28 & 1.44 \\
\hline NC7401 & Yes & $180-600$ & $>10$ & 48 & 612 & $>120$ & 0.94 & 0.22 & 1.95 \\
\hline RIVM BC 124 & Yes & $60-90$ & 10 & 48 & 369 & 149 & 1.00 & 0.24 & 1.19 \\
\hline RIVM BC 379 & No & $7-9$ & $>10$ & 48 & 289 & 58 & 1.45 & 3.72 & 1.15 \\
\hline RIVM BC 67 & Yes & $20-30$ & 10 & 48 & 270 & 120 & 0.93 & 1.32 & 1.79 \\
\hline SDA GR177 & No & 70 & 10 & 48 & 489 & $>120$ & 0.91 & 0.07 & 2.16 \\
\hline UHDAM CIF1 & No & $60-100$ & $>10$ & 48 & 68 & 7 & 4.01 & 0.60 & 2.12 \\
\hline UHDAM CIF3 & No & $10-80$ & $>10$ & 48 & 371 & 3 & 1.53 & 0.41 & 1.09 \\
\hline UHDAM 3/pkl & No & $70-160$ & $>10$ & 48 & 372 & $>120$ & 0.66 & 0.20 & 2.45 \\
\hline UHDAM B315 & Yes & $50-90$ & 10 & 48 & 129 & 34 & 2.13 & 0.49 & 0.72 \\
\hline UHDAM ML127 & Yes & $130-230$ & 10 & 48 & 318 & 6 & 1.40 & 0.48 & 1.12 \\
\hline UHDAM NS-115 & No & $1200-1600$ & $>10$ & 48 & 341 & 148 & 1.00 & 0.25 & 1.45 \\
\hline
\end{tabular}

nd: not determined.

${ }^{\text {a }}$ The range for results from three independent cultures are given.

${ }^{\mathrm{b}} \mathrm{D}$, decimal reduction time at $90{ }^{\circ} \mathrm{C} ; \delta$, time to first decimal reduction at $90{ }^{\circ} \mathrm{C}$; Viability loss, $\log _{10}$ bacterial reduction after $120 \mathrm{~min}$ at $90^{\circ} \mathrm{C}$.

${ }^{c}$ Germination is expressed as $\log _{10}\left(N_{0} / M\right)$, where $N_{0}$ is the initial spore number and $N$ is spore number after 7-day incubation at $7{ }^{\circ} \mathrm{C}$ and 50 -min incubation at $30{ }^{\circ} \mathrm{C}$ in nutrient broth (see Materials and methods for details).

${ }^{\mathrm{d}}$ Tested temperatures were $4{ }^{\circ} \mathrm{C}, 7^{\circ} \mathrm{C}$ and $10{ }^{\circ} \mathrm{C} ;>10^{\circ} \mathrm{C}$ indicates no growth observed at 10 ${ }^{\circ} \mathrm{C}$.

${ }^{\mathrm{e}}$ Tested temperatures were $42{ }^{\circ} \mathrm{C}, 45^{\circ} \mathrm{C}, 48{ }^{\circ} \mathrm{C}$ and $52{ }^{\circ} \mathrm{C}$. 
Table 3.

Characteristics of $B$. cereus strains connected to diarrheal foodborne outbreak tested in this work

\begin{tabular}{|c|c|c|c|c|c|c|c|}
\hline \multirow[t]{2}{*}{ Strain $^{\text {a no. }}$} & \multicolumn{2}{|c|}{$\begin{array}{l}\text { Temperature growth } \\
\text { limits }\left({ }^{\circ} \mathrm{C}\right)\end{array}$} & \multicolumn{3}{|c|}{$\begin{array}{l}\text { Heat resistance parameters of spores } \\
\text { at } 90^{\circ} C^{b}\end{array}$} & \multicolumn{2}{|c|}{$\begin{array}{l}\text { Germination of } \\
\text { spores at }^{\mathrm{b}}\end{array}$} \\
\hline & Lower $^{\text {b }}$ & Upper $^{b}$ & $D$ (min) & $\delta(\min )$ & Viability loss & $7^{\circ} \mathrm{C}$ & $30^{\circ} \mathrm{C}$ \\
\hline 98HMPL63 & 7 & 45 & 45 & 3 & 6.57 & 2.03 & 2.43 \\
\hline F2081A/98 & 7 & 48 & 29 & 5 & $>3.42$ & 2.00 & 2.91 \\
\hline F2085/98 & 10 & 48 & 52 & 3 & 5.58 & 2.10 & 2.67 \\
\hline F3371/93 & 7 & 45 & 47 & 23 & 5.24 & 3.94 & 3.47 \\
\hline F3453/94 & 10 & 45 & 115 & 28 & 2.40 & 0.18 & 1.91 \\
\hline F352/90 & 10 & 45 & 40 & 6 & 6.89 & 1.74 & 3.64 \\
\hline F4430/73 & 7 & 45 & 49 & 16 & 5.77 & 0.46 & 0.70 \\
\hline F4433/73 & 7 & 45 & 63 & 30 & 3.97 & 1.78 & 2.98 \\
\hline F528/94 & 7 & 45 & 40 & 2 & 6.91 & 2.88 & 2.00 \\
\hline F837/76 & 10 & 48 & 142 & 39 & 2.14 & 3.17 & 3.76 \\
\hline FH3502/72 & 7 & 48 & 300 & 120 & 0.93 & 2.32 & 4.44 \\
\hline IH41064 & 7 & 45 & 61 & 29 & 4.68 & 2.49 & 3.14 \\
\hline MHI 203 & 7 & 45 & 70 & 21 & 4.01 & 0.82 & 2.39 \\
\hline NRS 404 & 7 & 45 & 53 & 8 & 5.57 & 1.69 & 2.29 \\
\hline NVH 0075-95 & $>10$ & 48 & 185 & 53 & 1.77 & 0.26 & 1.37 \\
\hline NVH 0154-01 & 10 & 45 & 48 & 26 & 5.29 & 2.20 & 3.01 \\
\hline NVH 0165-99 & 7 & 48 & 69 & 1 & 4.55 & 1.84 & 1.57 \\
\hline NVH 0226-00 & 7 & 45 & 55 & 12 & 4.92 & 0.71 & 2.02 \\
\hline NVH 0230-00 & 7 & 48 & 92 & 20 & 2.86 & 3.40 & 3.63 \\
\hline NVH 0309-98 & 10 & 45 & 254 & 74 & 1.38 & 1.62 & 1.79 \\
\hline NVH 0391-98 & $>10$ & 45 & 60 & 41 & 4.34 & 0.70 & 2.44 \\
\hline NVH 0500-00 & 7 & 48 & 201 & 43 & 1.68 & 1.93 & 4.02 \\
\hline NVH 0597-99 & 7 & 48 & 41 & 29 & 6.10 & 1.79 & 2.44 \\
\hline NVH 0674-98 & 7 & 45 & 161 & 76 & 1.41 & 3.29 & 3.31 \\
\hline NVH 0784-00 & 7 & 45 & 92 & 57 & 2.84 & 2.97 & 3.81 \\
\hline NVH 0861-00 & 7 & 45 & 54 & 30 & 4.81 & 1.15 & 2.32 \\
\hline NVH 1104-98 & 7 & 42 & 74 & 12 & 3.76 & 3.00 & 3.90 \\
\hline NVH 1105-98 & 7 & 45 & 817 & $>120$ & 0.50 & 0.79 & 1.39 \\
\hline NVH 1230-88 & 7 & 45 & 49 & 41 & $>2.79$ & 1.10 & 3.59 \\
\hline NVH 141/1-01 & 7 & 45 & 79 & 15 & 3.95 & 2.43 & 3.69 \\
\hline NVH 1518-99 & $>10$ & 45 & 74 & 12 & 3.76 & 1.23 & 3.17 \\
\hline NVH 1519-00 & $>10$ & 48 & 93 & 67 & 3.43 & 0.39 & 2.30 \\
\hline NVH 1651-00 & 7 & 45 & 63 & 27 & 4.25 & 1.08 & 2.06 \\
\hline NVH 200 & 7 & 48 & 253 & 116 & 1.22 & 1.76 & 4.52 \\
\hline RIVM BC 122 & 10 & 45 & 81 & 2 & 4.10 & 2.35 & 2.16 \\
\hline RIVM BC 63 & 7 & 48 & 260 & 15 & 1.49 & 0.32 & 1.79 \\
\hline RIVM BC 90 & $>10$ & 48 & 162 & 35 & 1.96 & 0.23 & 0.64 \\
\hline UHDAM B106 & 7 & 48 & 301 & 106 & 1.04 & 2.14 & 3.16 \\
\hline UHDAM B154 & 7 & 48 & 48 & 4 & 5.91 & 4.04 & 3.82 \\
\hline UHDAM B217 & 7 & 48 & 131 & 43 & 2.43 & 0.55 & 2.11 \\
\hline
\end{tabular}

${ }^{a}$ Strains not producing the emetic toxin.

${ }^{\mathrm{b}}$ See Table 2 for legends. 
Table 4.

Characteristics of $B$. cereus food and environment strains tested in this work

\begin{tabular}{|c|c|c|c|c|c|c|c|}
\hline \multirow[t]{2}{*}{ Strain $^{\mathrm{a}}$ no. } & \multicolumn{2}{|c|}{$\begin{array}{l}\text { Temperature growth } \\
\text { limits }\left({ }^{\circ} \mathrm{C}\right)\end{array}$} & \multicolumn{3}{|c|}{$\begin{array}{l}\text { Heat resistance parameters } \\
\text { of spores at } 90^{\circ} \mathrm{C}^{\mathrm{b}}\end{array}$} & \multicolumn{2}{|c|}{ 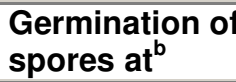 } \\
\hline & Lower $^{\mathrm{b}}$ & Upper $^{b}$ & $\begin{array}{l}D \\
\text { (min) }\end{array}$ & $\begin{array}{l}\delta \\
(\min )\end{array}$ & $\begin{array}{l}\text { Viability } \\
\text { loss }\end{array}$ & $7^{\circ} \mathrm{C}$ & $30^{\circ} \mathrm{C}$ \\
\hline INRA 1 & 4 & $<45$ & 60 & 0 & 6.48 & 2.87 & 0.80 \\
\hline INRA A3 & $>10$ & 45 & 208 & 83 & 1.17 & 1.48 & 2.45 \\
\hline INRA C24 & $>10$ & 48 & 152 & 57 & 1.66 & 0.25 & 2.32 \\
\hline INRA C3 & 10 & 45 & 46 & 18 & 5.68 & 2.52 & 2.55 \\
\hline INRA C57 & 10 & $<45$ & 49 & 31 & 4.79 & 3.01 & 1.35 \\
\hline INRA I20 & 4 & 45 & 48 & 2 & 6.52 & 1.72 & 0.62 \\
\hline INRA I21 & 7 & 45 & 50 & 3 & 5.86 & 2.00 & 1.11 \\
\hline INRA PA & $>10$ & 48 & 402 & 172 & 0.92 & 0.42 & 1.46 \\
\hline INRA SZ & 7 & 45 & 61 & 0 & 6.48 & 2.09 & 1.07 \\
\hline $\mathrm{MHI} 124$ & 10 & 48 & 140 & 9 & 2.27 & 0.75 & 2.32 \\
\hline $\mathrm{MHI} 13$ & 10 & 45 & 796 & 104 & 0.83 & 1.90 & 1.54 \\
\hline MHI 32 & 7 & 45 & 396 & 148 & 1.05 & 0.48 & 2.09 \\
\hline NVH 445 & 10 & 48 & 241 & 70 & 1.33 & 0.46 & 1.70 \\
\hline NVH 449 & 10 & 45 & 178 & 32 & 2.00 & 2.51 & 4.23 \\
\hline NVH 460 & 7 & 48 & 68 & 49 & 3.43 & 1.34 & 3.55 \\
\hline NVH 506 & 10 & 52 & 328 & $>120$ & 0.76 & 0.22 & 0.02 \\
\hline NVH 512 & 7 & 45 & 66 & 6 & 4.41 & 2.89 & 3.02 \\
\hline NVH 655 & 7 & 42 & 44 & 4 & 6.28 & 3.14 & 2.47 \\
\hline RIVM BC 485 & 7 & 45 & 140 & 51 & 2.18 & 1.92 & 2.84 \\
\hline RIVM BC 934 & $>10$ & 48 & 113 & 16 & 2.68 & 2.47 & 2.65 \\
\hline RIVM BC 938 & 7 & 48 & 64 & 29 & 4.45 & 2.99 & 3.22 \\
\hline RIVM BC 964 & 7 & 42 & 115 & 27 & 2.48 & 2.10 & 3.01 \\
\hline SDA 1R177 & 4 & 45 & 75 & 11 & 4.12 & 2.48 & 1.88 \\
\hline SDA 1R183 & 10 & 45 & 52 & 22 & 4.99 & 2.05 & 1.90 \\
\hline SDA 1R72 & 4 & 45 & 99 & 7 & 3.10 & 0.69 & 1.73 \\
\hline SDA GR285 & 7 & 48 & 105 & 0 & 4.31 & 1.00 & 2.54 \\
\hline SDA KA96 & 10 & 45 & 41 & 3 & 6.89 & 2.52 & 2.80 \\
\hline SDA MA57 & 7 & 48 & 42 & 10 & 6.26 & 2.22 & 0.67 \\
\hline SDA NFFE640 & 4 & 45 & 74 & 2 & 4.90 & 2.00 & 1.46 \\
\hline SDA NFFE647 & 4 & 42 & 68 & 7 & 4.01 & 1.19 & 0.43 \\
\hline SDA NFFE664 & 4 & 45 & 78 & 12 & 3.44 & 2.20 & 1.47 \\
\hline UHDAM 1IFI(13) & 10 & 48 & 152 & 87 & 1.91 & 0.60 & 0.12 \\
\hline UHDAM B102 & 10 & 48 & 92 & 3 & 3.71 & 1.51 & 1.76 \\
\hline UHDAM TSP9 & 10 & 45 & 66 & 26 & 3.96 & 2.09 & 2.57 \\
\hline WSBC10030 & 10 & 48 & 372 & $>120$ & 0.91 & 0.74 & 1.70 \\
\hline WSBC10204 & 4 & $\mathrm{ngo}^{\mathrm{C}}$ at 42 & $\mathrm{nt}^{\mathrm{d}}$ & nt & nt & $\mathrm{nt}$ & $\mathrm{nt}$ \\
\hline WSBC10286 & $>10$ & 48 & 367 & 80 & 1.04 & 0.26 & 1.27 \\
\hline WSBC10310 & $>10$ & 48 & $\mathrm{nt}$ & $\mathrm{nt}$ & nt & $\mathrm{nt}$ & $\mathrm{nt}$ \\
\hline WSBC10377 & 4 & ngo at 42 & 54 & 10 & 4.92 & 2.41 & 0.87 \\
\hline WSBC10395 & 7 & ngo at 42 & 164 & 2 & 3.37 & 2.54 & 1.84 \\
\hline WSBC10441 & 10 & 45 & 64 & 31 & 3.95 & 2.54 & 3.36 \\
\hline WSBC10466 & 7 & 48 & 59 & 27 & 4.46 & 2.36 & 2.87 \\
\hline WSBC10483 & 10 & 45 & 56 & 36 & 5.15 & 0.82 & 3.83 \\
\hline
\end{tabular}

a Strains not producing the emetic toxin.

${ }^{\mathrm{b}}$ See Table 2 for legends.

c ngo: no growth observed.

${ }^{d}$ nt: not tested, these strains did not produce spores in our experimental conditions. 
Table 5.

Temperature growth limits of emetic toxin-producing strains, diarrheal strains and foodenvironment strains of $B$. cereus

\begin{tabular}{|l|l|l|l|l|l|}
\hline \multicolumn{5}{|c|}{ Character } & \multicolumn{2}{|l|}{$\begin{array}{l}\text { Number of strains showing the character } \\
\text { among: }\end{array}$} & Significance $^{\text {a }}$ \\
\hline & $\begin{array}{l}\text { Emetic toxin- } \\
\text { producing } \\
\text { strains } \\
(\boldsymbol{n}=\mathbf{1 7})\end{array}$ & $\begin{array}{l}\text { Diarrheal } \\
\text { strains } \\
(\boldsymbol{n}=\mathbf{4 0})\end{array}$ & $\begin{array}{l}\text { Food- } \\
\text { environment } \\
\text { strains }(\boldsymbol{n}=\mathbf{4 3})\end{array}$ & \\
\hline $\begin{array}{l}\text { Lower } \\
\text { temperature } \\
\text { limit }\end{array}$ & $\begin{array}{l}\text { Growth at } \\
4{ }^{\circ} \mathrm{C} \\
\text { and/or 7 } \\
{ }^{\circ} \mathrm{C}\end{array}$ & 0 & 28 & 22 & $P<0.001$ \\
\hline & $\begin{array}{l}\text { No } \\
\text { growth at } \\
7{ }^{\circ} \mathrm{C}\end{array}$ & 17 & 12 & 21 & \\
\hline $\begin{array}{l}\text { Upper } \\
\text { temperature } \\
\text { limit }\end{array}$ & $\begin{array}{l}\text { Growth at } \\
48{ }^{\circ} \mathrm{C}\end{array}$ & 17 & 16 & 16 & \\
\hline & $\begin{array}{l}\text { No } \\
\text { growth at } \\
48{ }^{\circ} \mathrm{C}\end{array}$ & 0 & 24 & 27 & \\
\hline & & & & & \\
\hline
\end{tabular}

${ }^{a}$ Chi-square test.
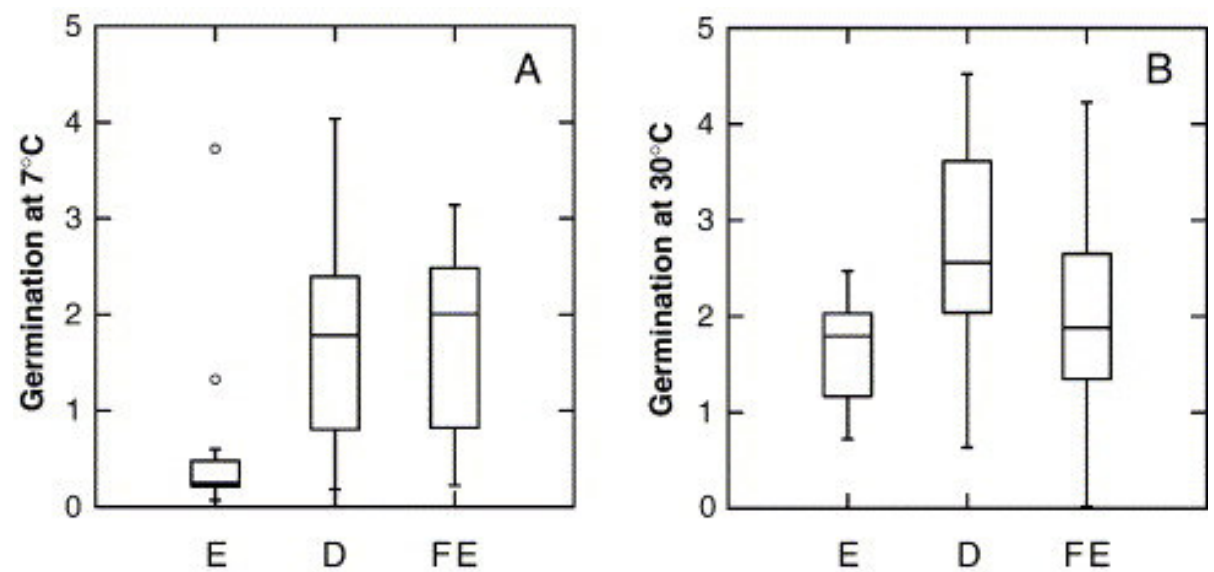

Fig. 1. Box-and-Whisker plot of the germination at $7{ }^{\circ} \mathrm{C}(\mathrm{A})$ and $30^{\circ} \mathrm{C}(\mathrm{B})$ of spores of emetic toxin-producing (E) $(n=17)$, diarrheal (D) $(n=40)$, and food-environment (FE) $(n=41) B$. cereus strains. Germination is expressed as $\log _{10}\left(N_{0} / N\right)$, where $N_{0}$ is the initial spore number and $N$ is spore number after 7 -day incubation at $7{ }^{\circ} \mathrm{C}$ and 50 -min incubation at $30{ }^{\circ} \mathrm{C}$ in nutrient broth (see Materials and methods for details). In the "Box-and-Whisker" representation, the central "box" covers the middle $50 \%$ of the data values between the lower and the upper quartiles. The central line in the "box" is at the median. "Whiskers" extend 1.5 times the box length (interquartile range). External values are plotted.

All emetic toxin-producing strains were able to grow at $48{ }^{\circ} \mathrm{C}$ while only $39 \%$ of the nonemetic toxin-producing strains (16 diarrheal and 16 food-environment strains) grew at this temperature (the difference in the frequency of strains growing at $48{ }^{\circ} \mathrm{C}$ in each category was significant at $P<0.001$ ) (Table 2, Table 3, Table 4 and Table 5). Spores of the emetic toxinproducing strains showed higher $D$-values $(P<0.001)$, $\delta$ values $(P<0.01)$, a higher survival 
after $120 \mathrm{~min}$ at $90{ }^{\circ} \mathrm{C}(P<0.001)$, and therefore a higher heat resistance, than spores of the non-emetic toxin-producing strains (Fig. 2). In contrast, spore germination patterns at both 7 ${ }^{\circ} \mathrm{C}$ and $30{ }^{\circ} \mathrm{C}$ and survival at $90{ }^{\circ} \mathrm{C}$ of diarrheal strains and food-environmental strains were similar. Parry and Gilbert (1980) also observed that the heat resistance of spores of 14 emetic strains was on average 6-fold higher than that of spores of 13 non-emetic strains isolated from rice. Quite recently, it has been shown that emetic toxin production is restricted to a single evolutionary lineage of $B$. cereus whereas diarrheal toxin producers are scattered throughout different phylogenetic clusters (Ehling-Schulz et al., 2005b). In particular emetic toxin-producing strains are unable to produce the $\mathrm{Hbl}$ toxin or don not carry the $\mathrm{hb} /$ genes, and only a few of them carry the cytK gene (Pirttijarvi et al., 1999 and Ehling-Schulz et al., $2005 \mathrm{~b})$. Our results are consistent with the phylogeny of $B$. cereus: all emetic toxin-producing strains rather thermophilic in contrast to diarrheal strains. Apart from the amount of cereulide produced by the strains, no other significant characteristics in growth profiles of diarrheal or food-environmental strains were observed. In particular none of the diarrheal strains produced the emetic toxin, without possible explanation at the present time of the significance of this observation.
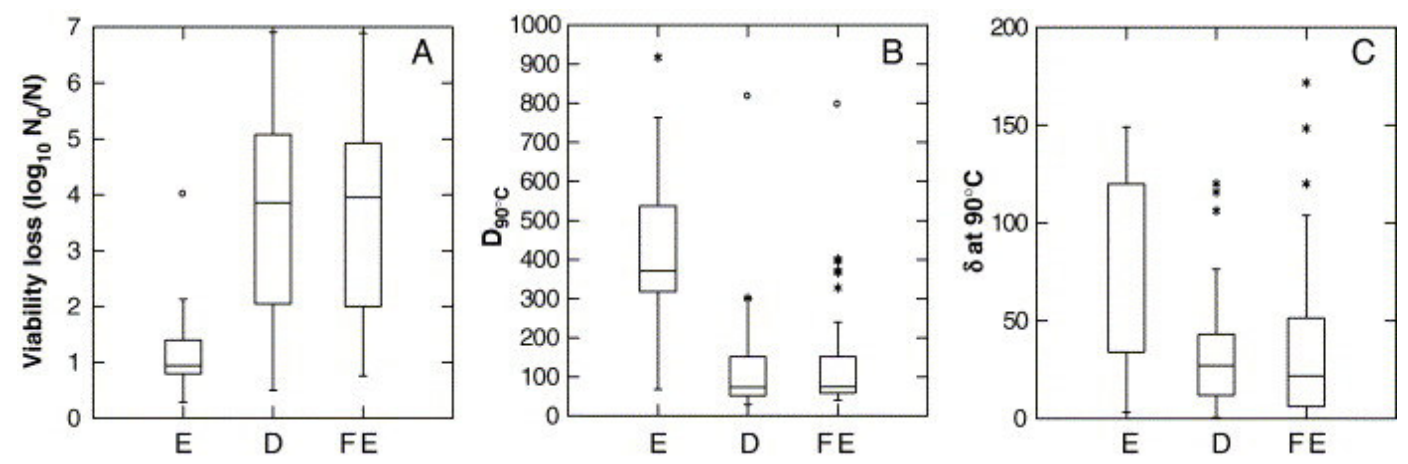

Fig. 2. Box-and-Whisker plots of the viability loss after $120 \mathrm{~min}$ at $90{ }^{\circ} \mathrm{C}(\mathrm{A}), D_{90}{ }^{\circ} \mathrm{C}(\mathrm{B})$, and time to first decimal reduction $(\delta)(C)$ of spores of emetic toxin-producing $(E)(n=17)$, diarrheal (D) $(n=40)$, and food-environment (FE) $(n=41) B$. cereus strains. Viability loss was expressed as the $\log _{10}\left(N_{0} / M\right)$ where $N_{0}$ is the initial spore number and $N$ is spore number after 120 -min heating at $120^{\circ} \mathrm{C}$ (See Materials and methods for details).

Emetic toxin-producing, diarrheal, and food-environment strains did not show any significant difference $(P>0.05)$ in their estimated growth kinetics from experiments performed at $24{ }^{\circ} \mathrm{C}$ and $37{ }^{\circ} \mathrm{C}$, and $\mathrm{pH} 5.0,7.0$ or 8.0 (data not shown).

In conclusion, our survey showed that emetic $B$. cereus strains possess specific growth characteristics (like a shift of growth limits towards higher temperatures combined with highly heat-resistant spores), which have to be taken into consideration if food safety issues are discussed. Our findings could help to assess the risks of special types of foods for emetic toxin production. For example, the poor ability to grow at low temperatures shows that emetic toxin-producing strains of $B$. cereus will pose a low risk in refrigerated foods. In contrast, the remarkable higher heat resistance of their spores favours their survival in heat-processed foods. Kramer and Gilbert (1989) proposed several recommendations to prevent outbreaks of $B$. cereus associated with cooked rice. These include either short time between preparation and consumption, keeping foods at high temperature $\left(>50^{\circ} \mathrm{C}\right.$ ) or rapid cooling (favoured by preparation in small quantities) followed by storage in the refrigerator, or avoiding storage at room temperature for more than $2 \mathrm{~h}$. Our study emphasized the importance of these recommendations and, in addition, showed that these advises should be extended to any kind of heat-processed foods and preheated foods that are kept warm, in restaurants and catering facilities for instance, to prevent the risk of emetic type of $B$. cereus food poisoning. 


\section{Acknowledgements}

This work has been carried out with the financial support from the Fifth European Community Framework Programme, under the Quality of life and Management of Living Resources specific programme, Contract QLK1-2001-00854, Preventing Bacillus cereus foodborne poisoning in Europe - Detecting hazardous strains, tracing contamination routes and proposing criteria for foods. The authors wish to express their gratitude to their fellow scientists and students who contributed to the work.

\section{References}

Agata et al., 1996 N. Agata, M. Ohta and M. Mori, Production of an emetic toxin, cereulide, is associated with a specific class of Bacillus cereus, Current Microbiology 33 (1996), pp. 67-69.

Andersson et al., 2004 M.A. Andersson, E.L. Jääskelainen, R. Shaheen, T. Pirhonen, L.M. Wijnands and M.S. Salkinoja-Salonen, Sperm bioassay for rapid detection of cereulide-producing Bacillus cereus in food and related environments, Current Microbiology 94 (2004), pp. 175-183.

Beattie and Williams, 1999 S.H. Beattie and A.G. Williams, Detection of toxigenic strains of Bacillus cereus and other Bacillus spp. with an improved cytotoxicity assay, Letters in Applied Microbiology 28 (1999), pp. 221-225.

Choma et al., 2000 C. Choma, M.-H. Guinebretiere, F. Carlin, P. Schmitt, P. Velge, P.E. Granum and C. Nguyen-the, Prevalence, characterisation and growth of Bacillus cereus in commercial cooked chilled foods containing vegetables, Journal of Applied Microbiology 88 (2000), pp. 617-625.

Claus and Berkeley, 1986 D. Claus and R.C.W. Berkeley, Genus Bacillus Cohn 1872, 174 AL In: P.H.A. Sneath, N.S. Mair, M.E. Sharpe and J.G. Holt, Editors, Bergey's Manual of Systematic Bacteriology, Williams and Wilkins, Baltimore (1986), pp. 1105-1139.

Doucet and Sloep, 1992 P. Doucet and P.B. Sloep, Mathematical Modeling in the Life Sciences, Ellis Horwood Limited, Chichester, England (1992).

Dufrenne et al., 1994 J. Dufrenne, P. Soentoro, S. Tatini, T. Day and S. Notermans, Characteristics of Bacillus cereus related to safe food production, International Journal of Food Microbiology 23 (1994), pp. 99-109.

Dufrenne et al., 1995 J. Dufrenne, M. Bijwaard, M.C. te Giffel, R. Beumer and S. Notermans, Characteristics of some psychotrophic Bacillus cereus isolates, International Journal of Food Microbiology 27 (1995), pp. 175-183.

Ehling-Schulz et al., 2004 M. Ehling-Schulz, M. Fricker and S. Scherer, Identification of emetic toxin producing Bacillus cereus strains by a novel molecular assay, FEMS Microbiology Letters 232 (2004), pp. 189-195.

Ehling-Schulz et al., 2005a M. Ehling-Schulz, V. Vukov, A. Schulz, R. Shaheen, M. Andersson, E. Märtlbauer and S. Scherer, Identification and partial characterization of the nonribosomal peptide synthetase gene responsible for cereulide production in emetic Bacillus cereus, Applied and Environmental Microbiology 71 (2005), pp. 113-115.

Ehling-Schulz et al., 2005b M. Ehling-Schulz, B. Svensson, M.-H. Guinebretiere, T. Lindbäck, M. Andersson, A. Schulz, M. Fricker, A. Christiansson, P.E. Granum, E. Märtlbauer, C. Nguyen-the, M. Salkinoja-Salonen and S. Scherer, Emetic toxin formation of Bacillus cereus is restricted to a single evolutionary lineage of closely related strains, Microbiology 151 (2005), pp. 183-197.

Fernández et al., 1999 A. Fernández, C. Salmerón, P.S. Fernández and A. Martinez, Application of a frequency distribution model to describe the thermal inactivation of two strains of Bacillus cereus, Trends in Food Science and Technology 10 (1999), pp. 158-162.

Finlay et al., 2000 W.J.J. Finlay, N.A. Logan and A.D. Sutherland, Bacillus cereus produces most emetic toxin at lower temperatures, Letters in Applied Microbiology 31 (2000), pp. 385-389.

Granum and Lund, 1997 P.E. Granum and T. Lund, Bacillus cereus and its food poisoning toxins, FEMS Microbiology Letters 157 (1997), pp. 223-228.

Guinebretière and Sanchis, 2003 M.H. Guinebretière and V. Sanchis, Bacillus cereus sensu lato, Bulletin de la Société Française de Microbiologie 18 (2003), pp. 95-103. 
Helgason et al., 2004 E. Helgason, N.J. Tourasse, R. Meisal, D.A. Caugant and A.B. Kolsto, Multilocus sequence typing scheme for bacteria of the Bacillus cereus group, Applied and Environmental Microbiology 70 (2004), pp. 191201.

Hill et al., 2004 K.K. Hill, L.O. Ticknor, R.T. Okinaka, M. Asay, H. Blair, K.A. Bliss, M. Laker, P.E. Pardington, A.P. Richardson, M. Tonks, D.J. Beecher, J.D. Kemp, A.B. Kolsto, A.C.L. Wong, P. Keim and P.J. Jackson, Fluorescent amplified fragment length polymorphism analysis of Bacillus anthracis, Bacillus cereus, and Bacillus thuringiensis isolates, Applied and Environmental Microbiology 70 (2004), pp. 1068-1080.

\begin{abstract}
Jääskeläinen et al., 2003 E.L. Jääskeläinen, M.M. Haggblom, M.A. Andersson, L. Vanne and M.S. SalkinojaSalonen, Potential of Bacillus cereus for producing an emetic toxin, cereulide, in bakery products: quantitative analysis by chemical and biological methods, Journal of Food Protection 66 (2003), pp. 1047-1054.
\end{abstract}

Johnson et al., 1982 K.M. Johnson, C.L. Nelson and F.F. Busta, Germination and heat resistance of Bacillus cereus spores from strains associated with diarrheal and emetic food-borne illnesses, Journal of Food Science 47 (1982), pp. 1268-1271.

Johnson et al., 1983 K.M. Johnson, C.L. Nelson and F.F. Busta, Influence of temperature on germination and growth of spores of emetic and diarrheal strains of Bacillus cereus in a broth medium and in rice, Journal of Food Science 48 (1983), pp. 286-287.

Kramer and Gilbert, 1989 J.M. Kramer and R.J. Gilbert, Bacillus cereus and other Bacillus species. In: M.P. Doyle, Editor, Foodborne Bacterial Pathogens, Marcel Dekker, New York (1989), pp. 21-70.

Mafart et al., 2002 P. Mafart, O. Couvert, S. Gaillard and I. Leguerinel, On calculating sterility in thermal preservation methods: application of the Weibull frequency distribution model, International Journal of Food Microbiology 72 (2002), pp. 107-113.

Nguyen-the et al., 2003 C. Nguyen-the, F. Carlin and M.H. Guinebretière, Bacillus cereus et sécurité des aliments, Bulletin de la Société Française de Microbiologie 18 (2003), pp. 104-112.

Parry and Gilbert, 1980 J.M. Parry and R.J. Gilbert, Studies on the heat resistance of Bacillus cereus spores and growth of the organism in boiled rice, Journal of Hygiene 84 (1980), pp. 77-82 (Cambridge).

Pirttijarvi et al., 1999 T.S.M. Pirttijarvi, M.A. Andersson, A.C. Scoging and M.S. Salkinoja-Salonen, Evaluation of methods for recognizing strains of the Bacillus cereus group with food poisoning potential among industrial and environmental contaminants, Systematic and Applied Microbiology 22 (1999), pp. 133-144.

Shinagawa, 1990 K. Shinagawa, Analytical methods for Bacillus cereus and other Bacillus species, International Journal of Food Microbiology 10 (1990), pp. 125-141. 